\title{
7
}

\section{General Principles and Customary Law in the EU Legal Order}

\author{
SAMANTHA BESSON
}

La formation d'une coutume communautaire est-elle concevable? Les traités sont encore trop récents pour en juger. Mais en soi, il ne faut pas exclure la possibilité, en présence surtout des nombreuses lacunes des traités, que des usages s'implantent, qu'ils soient acceptés par les institutions et par les Etats membres et que, pour finir, une conviction juridique vienne à s'installer à ce sujet.... Il n'est pas exclu que des conventions puissent s'établir sous forme coutumière.

P Pescatore, L'ordre juridique des Communautés européennes-Etude des sources du droit communautaire (Liège, Presses universitaires de Liège, 1975) 174

\section{Introduction}

Focusing on European Union customary law (EUCL) in a discussion pertaining to the general principles of EU law (EUGP) may sound surprising at first. Why broach one source of EU law, and a prima facie practically irrelevant one at that, to address another one? It is precisely because they are both (unwritten) sources of EU law that their comparison and relationship are arguably relevant. And this even more so as it is from the perspective of the doctrine of the sources of EU law that I propose to approach EUGP in this chapter.

What is striking about EUGP is their disproportionate quantitative and qualitative importance in $\mathrm{EU}$ law $^{1}$ by comparison to what is the case both in domestic

\footnotetext{
1 See eg S Besson, 'General Principles in International Law-Whose Principles?' in S Besson and P Pichonnaz (eds), Les principes en droit européen-Principles in European Law (Zurich, Schulthess, 2011) 19-64; J van Meerbeeck, 'Les principes généraux du droit de l'Union européenne' in Y Cartuyvels et al (eds), Les sources du droit revisitées - normes internationales et constitutionnelles, vol 1 (Bruxelles, Anthemis, 2012) 161-206; J Bengoetxea, 'Principia and Teloi' in S Besson and P Pichonnaz (eds), Les principes en droit européen-Principles in European Law (Zurich, Schulthess, 2011) 69-88; A Arnull, 'What Is a General Principle of EU Law?' in R de la Feria and S Vogenauer (eds), Prohibition of Abuse of Law: A New General Principle of EU Law (Oxford, Hart Publishing, 2011) 7-24; A von Bogdandy,
} 
legal orders ${ }^{2}$ and in the international legal order. ${ }^{3,4}$ This is surprising on at least two counts.

In contrast to what applies in domestic law ${ }^{5}$ and in international law, ${ }^{6}$ first of all, there is hardly any mention in practice of customary law among the unwritten sources of EU law. This is surprising because EU law is usually conceived of either as a regional regime of international (organisation) law or as a special municipal legal order. Even if it is correctly conceived as neither, it is striking to encounter a legal order that does not, or only rarely, recognises customary law among its sources. ${ }^{7}$ This is even more peculiar as the role of EUCL has been limited in practice since the inception of the EU legal order. As a matter of fact, it is still a

'Founding Principles of EU Law: A Theoretical and Doctrinal Sketch' (2010) 16 European Law Journal 95-111; D Simon, 'Les principes en droit communautaire' in S Claudal (ed), Les Principes en Droit (Paris, Economica, 2008) 287-304; U Bernitz, J Nergelius and C Cardner (eds), General Principles of EC Law in a Process of Development (Austin, Wolters Kluwer, 2008); X Groussot, General Principles of Community Law (Groningen, Europa Law Publishing, 2006); T Tridimas, The General Principles of EU Law, 2nd edn (Oxford, Oxford University Press, 2006); C Flaesch-Mougin, 'Typologie des principes de l'Union européenne' in Centre d'excellence Jean Monnet (ed), Le droit de l'Union européenne en principes, Liber amicorum en l'honneur de Jean Raux (Rennes, Apogée, 2006) 99-152; U Bernitz and J Nergelius (eds), General Principles of European Community Law (The Hague, Kluwer Law International, 2000); M Herdegen and K Wolters, 'General Principles of EU Law-The Methodological Challenge' in U Bernitz, J Nergelius and C Cardner (eds), General Principles of EC Law in a Process of DevelopmentReports from a Conference in Stockholm, 23-24 March 2007, organised by the Swedish Network for European Legal Studies (Alphen aan den Rijn, Kluwer Law International, 2008) 343-55; O Wiklund and J Bengoetxea, 'General Constitutional Principles of Community Law' in U Bernitz and J Nergelius (eds), General principles of European Community Law (The Hague, Kluwer Law International, 2000) 119-35; JA Usher, General Principles of European Community Law (London, Longman, 1998); D Simon, 'Y a-t-il des Principes Généraux du Droit Communautaire?' (1991) 14 Droits 73-86.

2 See eg G Tusseau, 'Métathéorie de la notion de principe dans la théorie du droit contemporaine. Sur quelques écoles de définition des principes' in S Caudal (ed), Les principes en droit (Paris, Economica, 2008) 75-112; R Guastini, 'Les principes de droit en tant que source de perplexité théorique' in S Caudal (ed), Les principes en droit (Paris, Economica, 2008) 113-26.

3 See eg G Gaja, 'General Principles of Law' in Max Planck Encyclopedia of Public International Law (Oxford, Oxford University Press, 2007), online edition, available at www.mpepil.com/, accessed 1 September 2015; R Kolb, 'Principles as Sources of International Law (with Special Reference to Good Faith)' (2006) 53 Netherlands International Law Review 1-36; E Jouannet, 'L'ambivalence des principes généraux' in R Huesa Vinaixa and K Wellens (eds), L'influence des sources sur l'unité et la fragmentation du droit international (Bruxelles, Bruylant, 2006) 115-54; H Ascensio, 'Principes généraux du droit' in Répertoire international Dalloz 2004.

${ }^{4}$ Importantly, my argument does not depend on the political nature of the EU, and in particular on whether it should be regarded as an international organisation or as a state. I am indeed assuming it has the (autonomous) legal order it claims to have and am only focusing on its law's sources. The type of international subjecthood of the EU does not matter for its capacity to have a legal order in the first place (see J Klabbers, 'The Concept of Legal Personality' (2005) 11 Ius Gentium 35-66). Of course, the EU's political nature can be relevant with respect to the identity of its law's subjects and hence, partly at least, to the grounds for its legitimacy. However, assuming for now that both a state and an international organisation can be democratic, the political nature of the EU does not seem decisive for the relevance of EUCL.

${ }^{5}$ See eg Art 1(2) of the 1907 Swiss Civil Code.

6 See eg Art 38(1)(b)(c) of the 1945 Statute of the International Court of Justice.

7 I am agnostic here about whether the usual sources of law (legislation, custom, principles) are a contingent feature of a legal order or a conceptual-normative one. The fact is that there are striking 
relatively young legal order and unwritten law should therefore be called to play an important gap-filling role, ${ }^{8}$ as confirmed ironically by the comparatively important gap-filling function of EUGP in EU law. Actually, even in long-established domestic legal orders where material customary law tends to diminish in relevance, customary law is still called to play a role in the institutional or constitutional realm. ${ }^{9}$ And the same could be said of the regional or functional customary law that often develops through established inter-state or institutional practice within international organisations (IOs). ${ }^{10}$

Secondly, in contrast to domestic and international law, there are no discussions in practice pertaining to the relationship between EUGP and EUCL. This is equally surprising because general principles are usually regarded, either interchangeably or at the same time, as both a type of norms and a source, at least in domestic and international law. This raises the difficulty of their relationship to other sources of law and especially to unwritten sources such as customary law. In fact, customary law is the source of many general principles of law qua norms, thus making its relationship to general principles qua source even more ambiguous. This may be exemplified by reference to the debate surrounding the legal positivist understanding of general principles, ${ }^{11}$ and especially the idea of 'judicial custom' qua social source of these principles in a legal order. Finally, general principles and customary law are not only both unwritten sources of law, but share common features in their process of identification and formation, thereby making the distinction between them often difficult. These three issues are well known in international law where the conflation between general principles and customary international law is common. The relationships between both sources are also frequently considered in domestic law.

Of course, the lack of existence or relevance of EUCL in practice depends on which practice one considers. To start with, there is very little discussion of EUCL in the case law of the Court of Justice of the European Union (CJEU), ${ }^{12}$ for reasons

commonalities on sources from one legal order to the other in practice. Thus, even if having customary law among its sources is a contingent feature of the domestic and international legal orders, it is worth wondering why EU law differs in this respect from both domestic and international law. See also JL Martí, 'Legitimacy and the Sources of International law' in S Besson and J d'Aspremont (eds), Oxford Handbook on the Sources of International Law (Oxford, Oxford University Press, 2018, forthcoming).

${ }^{8}$ See also P Pescatore, L'ordre juridique des Communautés européennes-Etude des sources du droit communautaire (Liège, Presses universitaires de Liège, 1975) 174

9 See eg T Blanchet and J Keller-Noëllet, 'Peut-on parler de "coutume" en droit de l'Union européenne?' in Y Cartuyvels et al (eds), Les sources du droit revisitées-Les normes internationales et constitutionnelles, vol 1 (Brussels, Anthemis, 2012) 207-52; JP Jacqué, 'La pratique des institutions communautaires et le développement de la structure institutionnelle communautaire' in R Bieber and G Ress (eds), The Dynamics of EU Law (Baden-Baden, Nomos, 1987) 377-405.

${ }^{10}$ See eg C Peters, 'Subsequent Practice and Established Practice of International Organizations: Two Sides of the Same Coin?’ (2011) 3 Goettingen Journal of International Law 617-42.

11 See eg Besson (n 1); C Semmelmann, 'General Principles in EU Law between a Compensatory Role and an Intrinsic Value' (2013) 19 European Law Journal 457-87.

12 As a matter of fact, the only explicit reference to the term 'custom' can be found in Opinion of AG Maduro in Case C-133/06 Parliament v Council, [2008] ECR I-03189 EU:C:2007:551, paras 27-29. 
that I will identify and discuss later. True, this need not be representative of the rest of the practice of EU law. EUCL can arise from inter-institutional or inter-state practice and may, as a result, be identified and, arguably, even validated by other EU institutions than the CJEU. Besides, one should not underestimate the role of scholarship in the acknowledgement of the existence and relevance of a given source in the legal practice. This is because of the role of the doctrine of sources in the latter's functioning. Just as curiously, however, there has been very little scholarly interest in EUCL to date, ${ }^{13}$ and even less so in its relationship to EUGP. ${ }^{14}$

Most of the EU law literature that discusses EUCL is quite ancient. Moreover, it stems from French-speaking or Dutch-speaking EU law scholarship, thereby confirming, of course, how little interest there has been overall for the topic of sources in EU law in English-speaking scholarship over time. ${ }^{15}$ All the same, the little EU law literature there is about EUCL is generally favourable to it and emphasises its interesting features. ${ }^{16}$ Curiously, even the literature on international law in the EU legal order, and how both legal orders influence each other, does not pick up on EUCL. International lawyers and EU external relations lawyers alike focus on customary international law (CIL) and how it has been received within EU law (eg its validity, rank and effects) or, conversely, how the EU's practice has been contributing to the identification and/or formation of $\mathrm{CIL}^{17}$ — whether on its own, in the EU's respective spheres of competence, or in lieu of and for its Member States as

13 See eg B de Witte, 'Sources and the Subjects of International Law: The EU and the Sources of International Law' in S Besson and J d'Aspremont (eds), Oxford Handbook on the Sources of International Law (Oxford, Oxford University Press, 2018, forthcoming); Blanchet and Keller-Noëllet (n 9); D Kochenov, 'EU Enlargement Law: History and Recent Developments: Treaty-Custom Concubinage?' (2005) 9(6) European Integration online Papers available at http://eiop.or.at/eiop/texte/2005-006a.htm, accessed 1 September 2015; T Koopmans, 'General Principles of Law in European and National Systems of Law' in U Bernitz and J Nergelius (eds), General Principles of European Community Law (The Hague, Kluwer Law International, 2000) 25-34; H Schermers and DF Waelbroeck, Judicial Protection in the European Communities, 5th edn (London, Kluwer Law and Taxation Publishers, 1992) 98; Jacqué (n 9); A Bleckmann, 'Zur Funktion des Gewohnheitsrechts im europäischen Gemeinschaftsrecht' (1981) 16 Europarecht 101-23; Pescatore (n 8).

${ }^{14}$ Compare the separate chapters by Blanchet and Keller-Noëllet (n 9) and Van Meerbeeck (n 1) and their lack of cross-references.

15 Compare eg JP Jacqué, Droit institutionnel de l'Union européenne, 8th edn (Paris, Dalloz, 2015) $511 \mathrm{ff}$; C Blumann and L Dubouis, Droit institutionnel de l'Union européenne, 5th edn (Paris, LexisNexis, 2013) 543ff with eg TC Hartley, The Foundations of European Union Law, 8th edn (Oxford, Oxford University Press, 2014) 83ff and 203ff; P Craig and G de Búrca, EU Law, Text, Cases, and Materials, 6th edn (Oxford, Oxford University Press, 2015) 105ff.

16 Contra: Blumann and Dubouis (n 15) 544.

17 See eg J Malenovsky, 'Le juge et la coutume internationale: perspectives de l'Union européenne et de la Cour de justice' (2013) 12 Law and Practice of International Courts and Tribunals 217-41; T Konstadinides, 'When in Europe: Customary International Law and EU Competence in the Sphere of External Action' (2012) 13 German Law Journal 1177-201; A Gianelli, 'Customary International law in the European Union' in E Cannizzaro et al (eds), International Law as Law of the European Union (Leiden/Boston, Martinus Nijhoff, 2012) 93-110; F Hoffmeister, 'The Contribution of EU Practice to International Law' in M Cremona (ed), Developments in EU External Relations Law (Oxford, Oxford University Press, 2008) 37-128; J Vanhamme, 'Formation and Enforcement of Customary International Law: The European Union's Contribution’ (2008) 39 Netherlands Yearbook of International Law $127-54$. 
practised by other IOs. ${ }^{18}$ This neglect is particularly intriguing as the existence of EUCL definitely affects the contribution of the EU to the development of CIL. Of course, the latter may occur without EUCL, but the existence of EUCL conditions the development of some norms of CIL, such as international human rights law. Generally speaking, the existence of customary law internal to an IO is approached by international law scholars exclusively from the perspective of its contribution to CIL (or, worse, as subsequent international treaty practice under Article 31(3) (c) of the Vienna Convention on the law of treaties (VCLT)), and rarely as a source of IO law in itself and hence as functional or regional customary law. ${ }^{19}$

The neglect of EUCL, and its relationship to EUGP, in both the practice and scholarship of EU law is even more surprising as the stakes in matters relative to the sources of law are high in any legal order. This should be true of the EU legal order as well. Among these stakes, one should, first of all, mention the concern for the legitimacy of EU law. Sources should indeed be organised in such a way that the EU law they produce can claim legitimate authority. Given the specificities of the EU legal order, the duality of its subjects (individuals and states), and in particular its democratic claims to inclusion and participation, ${ }^{20}$ the issue of the legitimacy of EUCL and EUGP arises differently than in either domestic or international law, but especially in the latter. A second stake is the allocation and balance of powers, both horizontally among EU institutions (Article 13(2) TEU) and vertically among the EU and its Member States (Articles 4(1)(3) and 5(1)(2) TEU). Sources of EU law should indeed be organised so as to respect that idiosyncratic balance. Again, these procedural constraints differ from what may apply in the domestic legal order, but especially also in the international legal order. A third concern is a constitutional one. Sources of EU law should be organised so as to respect the constraints set by the EU constitutional order, ${ }^{21}$ and especially within the EU Treaties. This hierarchical dimension of the sources of EU law distinguishes them from those of the international legal order in particular, and affects both EUCL and EUGP and their potential relationship.

There are many reasons one could put forward for the comparative imbalance between EUCL and EUGP in the EU legal order. Some are inherent to the Union's supranational nature and idiosyncratic democratic legitimacy, whereas others pertain to changes in the relationship between EU law and international law, in the allocation of powers horizontally between EU institutions or vertically between

18 See eg J Wouters and P De Man, 'International Organizations as Law-Makers' in J Klabbers and $\AA$ Wallendahl (eds), Research Handbook on the Law of International Organizations (Cheltenham, Edward Elgar, 2011) 190-224; Third report (A/CN.4/682) on identification of customary international law presented by Sir Michael Wood, Special Rapporteur, on the sixty-seventh session of the ILC, 27 March 2015, 46-54.

19 See eg JE Alvarez, International Organizations as Law-Makers (Oxford, Oxford University Press, 2005). See, however, Peters (n 10).

20 See Opinion of AG Maduro in Case C-133/06 Parliament v Council (n 12) para 29.

21 See ibid, para 29. See, more generally, eg Opinion 2/13 (Opinion pursuant to Article 218(11) TFEU) EU:C:2014:2454, para 158. 
the EU and the Member States, and in the role of the CJEU and its case law in the EU legal order. As I will argue, some of these reasons are under strain currently, thereby leading to potential developments in the practice of EUCL. Understanding the specificities of EU law with respect to EUCL, and its relationship to EUGP, and the reasons for these peculiarities of the EU legal order in comparison to both domestic and international law constitutes this chapter's first aim. Its second objective is to explain why and how some EUGP could be better approached as EUCL.

Accordingly, my argument will be three pronged. In section II, I will briefly account for three theoretical issues pertaining to general principles in EU law: their types, sources and functions in the EU legal order in comparison to domestic and international law. Section III will address EUCL and especially its types and functions, but also how it differs from other written and unwritten sources of EU law, how it relates to them and why it has had so little relevance in practice, still by comparison to domestic and international law. In section IV, I will argue for a stronger relationship between EUGP and EUCL in terms of sources of EU law. I will illustrate the importance of doing so with respect to EU fundamental rights which are the epitome of EUGP.

\section{General Principles in EU Law}

General principles are broadly used and referred to throughout the EU Treaties and within the CJEU's case law. Interestingly, general principles have a specific nature (II.A), specific sources (II.B) and a specific role (II.C) in EU law in comparison to what applies in domestic and international law.

\section{A. Types of General Principles in EU Law}

In a nutshell, EUGP can be understood as legal principles, ie as (i) fundamental legal norms that are (ii) structurally indeterminate. ${ }^{22}$

As it is the case domestically and internationally, the addition of the qualifications 'general' and/or 'fundamental' does not bring much to the extent that all legal principles are usually both general and fundamental. Although principles may apply to public authorities or to individuals, ${ }^{23}$ this article focuses on general principles of public law, ie on principles that apply to public authorities whether EU Member States or EU institutions. These general principles can also be referred to as constitutional principles.

22 See Guastini (n 2).

${ }^{23}$ See Arnull (n 1). 
There are four types of general principles in EU law. EU lawyers, like international lawyers, are familiar, first of all, with general principles 'common to the laws of the Member States' that stem from common domestic traditions such as EU fundamental rights; second, with 'general principles of international law' such as pacta sunt servanda; and, third, 'general principles of EU law' such as direct applicability that are specific to the functioning of the EU. This third category entails all general principles that pertain to the constitutional and institutional articulation and organisation of the EU. ${ }^{24} \mathrm{EU}$ law also knows of a fourth category of general principles, however, that comes close to the general principles one finds in domestic law: 'general principles of law'. These are the principles one encounters in any domestic legal system in Europe, such as legal security in particular.

\section{B. Sources of General Principles in EU Law}

In terms of sources, EUGP are both considered a type of EU legal norm and a source of EU (unwritten) primary law. ${ }^{25}$ One may derive the latter from Article 263(1) and Article 340(2) TFEU in particular.

Of course, general principles of EU law qua source of EU law include as a priority general principles that stem from common domestic traditions. There is actually an important mutuality of general principles that arise from domestic law, become European general principles and influence domestic principles in return. This has been the case for the principle of proportionality, in particular.

Interestingly, the CJEU is quite specific regarding the method and criteria for the identification of the EUGP it considers as a source of EU law, ie those stemming from common domestic traditions. Denys Simon refers to that method as a 'méthode éclectique, sélective et filtrante.' ${ }^{26}$ The CJEU starts by a comparative law analysis, although it has done so less and less rigorously in recent times and leaves it to the Advocate General in most cases. ${ }^{27}$ The criteria are, first of all, a commonality test that does not usually require unanimity among states or even a majority thereof; ${ }^{28}$ and, secondly, a transposability test the success of which depends on how well the principles fit the overall structure and objectives of

\footnotetext{
24 See von Bogdandy (n 1); N Tsagourias, 'The Constitutional Role of General Principles of Law in International and European Jurisprudence' in N Tsagourias (ed), Transnational ConstitutionalismInternational and European Models (Cambridge, Cambridge University Press, 2007) 71-106.

25 See P Pescatore, 'Les principes généraux du droit en tant que source du droit communautaire' in P Pescatore (ed), Études de droit communautaire européen 1962-2007 (Bruxelles, Bruylant, 2008) 691-730.

26 See Simon, 'Y a-t-il des Principes Généraux' (n 1) and Simon, 'Les principes en droit communautaire' (n 1).

27 See Arnull (n 1).

28 See Opinion of AG Lagrange in Case C-14/61 Koninklijke Nederlandsche Hoogovens en Staalfabrieken v ECSC High Authority [1962] ECR 485 EU:C:1962:19.
} 
the EU. ${ }^{29}$ In view of the case law, the two tests tend to merge into one another as certain domestic traditions are held to be compatible with the general objectives of the EU and hence to be sufficiently common, while others do not for the very same reasons. ${ }^{30}$

EUGP also have other sources than domestic general principles, and in particular (written) primary EU law, but also the CJEU's case law.

Starting with the latter, first of all, whether one sees the CJEU as only interpreting and specifying the EUGP one finds in EU primary law, or actually as creating them or turning them into EU law through judicial custom, its case law is crucial to general principles. Judicial law amounts indeed to the most important source of legal principles as the latter need to be identified, but also interpreted even if they are guaranteed legally and pre-exist judicial interpretation. By nature, legal principles require interpretation and a normative assessment in every case. Arguably, not only do legal principles require the judiciary, ${ }^{31}$ but judges need legal principles to exercise their functions fully. ${ }^{32}$

As in domestic and international law, secondly, general principles are gradually specified and codified into primary or secondary EU law. As I explained before, this does not prevent their judicial interpretations from developing them further (see eg Article 6(3) TEU in the context of EU fundamental rights). The distinction between written and unwritten general principles is fluid, as a result. Implicit principles often get codified and become explicit, but they subsist as implicit principles. Implicit principles may actually also be extracted from explicit ones through interpretation. As a result, codified principles may impact on codified law through a retroaction process.

The CJEU has not yet defined a strict method as to how to identify those general principles of EU law that do not stem from primary EU law-and do not derive from domestic traditions qua autonomous source of EU law either. ${ }^{33}$ This may be explained by the unease the idea of judicial law creates in general. ${ }^{34}$ By contrast to international law, however, the issue is not so much the lack of hierarchy or exclusivity of the judiciary and its lack of compulsory jurisdiction or of

29 See Case C-11/70 Internationale Handelsgesellschaft mbH v Einfuhr- und Vorratsstelle für Getreide und Futtermittel [1970] ECR 1125 EU:C:1970:114, para 4.

${ }^{30}$ Compare Case C-159/90 Society for the Protection of Unborn Children Ireland $v$ Grogan and others [1991] ECR I-4685 EU:C:1991:378 or Case C-341/05 Laval un Partneri [2007] ECR I-11767 EU:C:2007:809 with Case C-36/02 Omega Spielhallen- und Automatenaufstellungs-GmbH $v$ Oberbürgermeisterin der Bundesstadt Bonn [2004] ECR I-09609 EU:C:2004:614, paras 34ff.

31 See also P Brunet, 'Les principes généraux du droit et la hiérarchie des normes' in D de Béchillon, P Brunet, V Champeil-Desplats and E Millard (eds), L'architecture du droit. Mélanges en l'honneur de Michel Troper (Paris, Economica, 2006) 207-21.

32 See eg Groussot (n 1) 105ff.

33 See eg the discussion pertaining to the existence of a general principle of equality of shareholders or of abuse of law in the Case C-101/08 Audiolux and Others [2009] ECR I-9823 EU:C:2009:626 and Case C-255/02 Halifax and Others [2006] ECR I-1609 EU:C:2006:121.

34 See Herdegen and Wolters (n 1 ). 
democratic legitimacy and accountability. One may indeed argue that the CJEU, and the European judicial dialogue that is so specific to the European legal order lato sensu, have actually developed in the way they did through the elaboration of general principles. ${ }^{35}$ Rather, the challenge to judicially created EUGP has to do with the vertical and horizontal division of powers within the EU, on the one hand, and between the EU and its Member States, on the other. ${ }^{36}$ Recent case law shows how justified these fears about a general principles' 'competence creep' are. ${ }^{37}$ Interestingly, the CJEU has actually responded to those concerns recently by not over-interpreting general principles. ${ }^{38}$

Finally, in terms of rank, it follows from the nature and role of EUGP that they need to be interpreted and specified when applied in concrete circumstances and, in most cases, balanced against other legal principles. Their balancing is guided by the moral and political values they protect. It cannot indeed occur by reference to a formal hierarchy of legal norms: principles stem from different sources, on the one hand, and even when they stem from one single source such as judicial law, they are meant to refer the interpreter to moral values and hence relate to an axiological hierarchy and not a legal one, on the other. This becomes clear when one thinks of constitutional principles whose constitutional nature can derive à la fois from their constitutional entrenchment and from their use in constitutional judgements, without any difference being made either way as to their rank in case of balancing. In the context of EU law, one may actually consider that the constitutional function of (most) general principles, combined with their normative importance, would justify granting them constitutional rank in most cases. ${ }^{39}$ This has consequences in turn for the formal hierarchy of sources within EU law: if there is a hierarchy between EUGP and EU primary law, indeed, it is a material one at most (see also Article 52(4) EU Fundamental Rights Charter (EUFRC) a fortiori regarding EU fundamental rights). And the same may be said of their relations to one another.

35 See Groussot (n 1).

36 See S Prechal, 'Competence Creep and General Principles of Law' (2010) 3 Review of European Administrative Law 5-22. Contra: K Lenaerts and J Gutierrez Fons, 'The Constitutional Allocation of Powers in the EU and General Principles' (2010) 47 Common Market Law Review 1629-69, 1630.

37 See eg in the EU fundamental rights context: Case C-34/09 Gerardo Ruiz Zambrano v Office national de l'emploi (ONEm) [2011] ECR I-1177 EU:C:2011:124. See eg in the EU private law context: Case C-144/04 Werner Mangold v Rüdiger Helm [2005] ECR I-9981 EU:C:2005:709; Case C-555/07 Kücückdeveci [2010] ECR I-365 EU:C:2010:21; Case C-176/12 Association de médiation sociale [published in the electronic Reports of Cases] EU:C:2014:2. See T Tridimas, 'Horizontal Effect of General Principles: Bold Rulings and Fine Distinctions' in U Bernitz, X Groussot and F Schulyok (eds), General Principles of EU Law and European Private Law (Alphen aan den Rijn, Kluwer Law International, 2013) 213-232.

38 See eg Case C-101/08 Audiolux (n 33); Case C-255/02 Halifax (n 33). See also, most recently, Case C-176/12 Association de médiation sociale (n 37).

39 See Joined Cases C-402/05 P and C-415/05 P Kadi and Al Barakaat International Foundation $v$ Council and Commission [2008] ECR I-06351 EU:C:2008:461, paras 307-08 (on fundamental rights); Opinion 2/13 (n 21) para 191 (on mutual trust). 


\section{Functions of General Principles in EU Law}

The functions of general principles in EU law follow closely the different functions general principles have in domestic law, but also in international law. ${ }^{40}$ General principles are both an aid to and a constraint on the judicial interpretation of EU law. ${ }^{41}$ Their reference to values helps to justify other EU law norms, but also contributes to the development of the rule of law in EU law and hence to the legitimacy of EU law as a whole.

The two functions of general principles one can distinguish in domestic and international law, ie gap-filling and coherence, can also be identified in the CJEU's practice. They have evolved both quantitatively and qualitatively in the EU legal order, however.

General principles helped to fill gaps, first of all, while EU law was developing. It seems from the recent case law, however, that there are too many potential principles available currently and that the CJEU often chooses to leave a gap open nowadays rather than fill it with yet another principle. ${ }^{42}$ One may also observe how general principles codified in EU primary law are constantly being reinterpreted by the CJEU, thus ensuring a dynamic understanding of EU law. In qualitative terms too, the gap-filling function has turned into an intervalidation function where general principles allow principles to be transferred from one legal order to the other, and in particular from domestic or international law into EU law, while respecting the autonomy of each of the respective legal orders.

Secondly, general principles also ensure the coherence of EU law. Here again, coherence has evolved with EU law and the greater integration between legal orders in the EU. Although their invocation does not imply hierarchy or unity, general principles contribute to the integrity of the European legal order lato sensu and hence preserve the legal pluralism that prevails between the EU legal order and that of its Member States. ${ }^{43}$ General principles can even be regarded as a way of providing materially superior norms and a transitive normative hierarchy that can allow EU law and general international law to be articulated in richer terms than dualist ones within the European legal order lato sensu. ${ }^{44}$

\section{EU Customary Law}

Although it is the most important unwritten source of law in both domestic and international law, customary law has received very little recognition in the practice

40 See Guastini (n 2).

${ }^{41}$ See also Bengoetxea (n 1).

42 See Case C-101/08 Audiolux (n 33) and Case C-255/02 Halifax (n 33).

43 See S Besson, 'From European Integration to European Integrity. Should European Law Speak with Just One Voice?' (2004) 10 European Law Journal 257-81.

44 See eg Opinion of AG Maduro in Joined Cases C-402/05 P and C-415/05 P Kadi and Al Barakaat International Foundation v Council and Commission [2008] ECR I-6351 EU:C:2008:11. 
and scholarship of EU law. In what follows, and by reference to the structure of the discussion of EUGP adopted in the previous section, I will consider the different types of EUCL one encounters in practice (III.A), their relationship to other sources of EU law (III.B) and their various functions (III.C), always by comparison to what is the case in domestic and international law.

\section{A. Types of EU Customary Law}

EUCL can be understood, like customary law in general, as a normative practice, ie (i) a general, coherent and regular practice (ii) regarded as law and hence as legally binding.

Confirmation of the applicability of the so-called two-element doctrine in EU law may be found in the CJEU's case law. ${ }^{45}$ There is very little information in that very case law, however, about how these criteria actually work. Of course, as I explained before, the CJEU's case law is extremely limited on EUCL in general and the reasoning pertaining to its ascertainment even more. Domestic and international courts are not usually very specific about the criteria they use for the determination of customary law in any case.

Depending on the identity of the subjects and the object of customary law, one may distinguish between different types of EUCL: inter-individual, interinstitutional and/or inter-state EUCL; and material and/or constitutional EUCL.

First of all, the subjects of EUCL could be any of the subjects of EU law: individuals, EU institutions or EU Member States. This is what one would expect from a comparison with domestic and international customary law. The subjects of any norm of customary law are indeed those practising what could thereby become a custom. In EU law, EUCL has developed mostly between EU institutions and/ or between EU Member States. This is a consequence of the object of EUCL, as we will see next, but also of the sheer scope of the general EU practice needed to give rise to inter-individual EUCL and the difficulty of meeting that condition in practice at EU level. As it is the case in international law, inter-state EUCL may also arise from a sufficiently general, regular and coherent intrastate practice.

Secondly, EUCL may be either material or institutional depending on whether its object is any part of EU material law or only EU institutional law. This is a distinction one encounters within domestic customary law where customary law has progressively, and primarily due to its gradual codification, become mostly institutional or constitutional. Constitutional customary law is also referred to domestically as 'constitutional custom' or 'constitutional convention'. In EU law, constitutional customary law is also the most common type of EUCL one can encounter. ${ }^{46}$ Its norms pertain to various constitutional aspects of the EU, and in

45 See Case C-230/81 Luxembourg v Parliament [1983] ECR 255 EU:C:1983:32, para 44.

46 See Blanchet and Keller-Noëllet (n 9) 217; Jacqué (n 9) 377. 
particular to inter-institutional relations or intra-institutional organisation. However, this does not preclude the development of material EUCL, in principle. In this chapter, I will focus on constitutional EUCL, whether it is inter-institutional or inter-state, as this provides a nice contrast to the constitutional EUGP discussed in the previous section.

The examples of constitutional EUCL one finds in practice may be organised under two headings: inter-institutional and inter-state. ${ }^{47}$ There are more examples of the former than of the latter, for reasons that have to do with the jurisgenerative effects of the self-organisation powers of EU institutions and their duties of loyal co-operation. ${ }^{48}$

Of course, examples of EUCL are mostly historical to the extent that EUCL, once it is sufficiently established to be qualified as such, is often rapidly codified into EU primary law for reasons of legal security. Inter-institutional EUCL is also often turned into inter-institutional agreements. To that extent, EUCL may be compared to EUGP whose relationship to EU primary law is dynamic and characterised by the toing and froing of codification and interpretation processes. Among historical examples of norms of inter-institutional EUCL, on the one hand, one may mention the 1966 Compromis du Luxembourg ${ }^{49}$ or the Parliament's role in the consultation procedure. ${ }^{50}$ Both practices arose as custom and were then codified into EU primary law. Historical examples of inter-state EUCL, on the other, may be found in the EU standards for enlargement ${ }^{51}$ or for the election of CJEU judges (Article 255 TFEU).

As I explained in the introduction, it is difficult to find many examples of EUCL in the CJEU's case law. The latter only rarely mentions inter-institutional practices, and, even more rarely, inter-state practices. When it does, moreover, it does not refer to them expressly as 'customary'. The only exception is Advocate General Maduro's 2007 Opinion which refers explicitly to 'extra-statutory customs' and to 'precedents' from the institutions or Member States. ${ }^{52}$

Unsurprisingly, therefore, the Court's reasoning is also usually very brief. The CJEU's case law on EUCL confirms the distinction between inter-institutional and inter-state customary law, albeit not nominally, of course. The Court has never accepted a case of inter-state customary law to date. The reasons given are either that such law could be equated to an amendment of the EU Treaties contrary to Article $48 \mathrm{TEU}$, as in the Defrenne I case, ${ }^{53}$ or that it would be overriding or

\footnotetext{
47 See Blanchet and Keller-Noëllet (n 9) 221-22, 225-38, 244-47; Blumann and Dubouis (n 15) $455-56$.

48 See Jacqué (n 9) 381-93.

49 See eg Blumann and Dubouis (n 15) 260ff; Craig and G de Búrca (n 15) 134-35.

50 See Case C-138/79 Roquette frères [1980] ECR 3333 EU:C:1980:249; Case C-65/93 Parliament $v$ Council [1995] ECR I-643 EU:C:1995:91.

51 See Case C-93/78 Mattheus v Doego [1978] ECR 2203 EU:C:1978:206. See also Kochenov (n 13).

52 See Opinion of AG Maduro in Case C-133/06 Parliament $v$ Council (n 12) paras 27-29.

53 See Case C-43/75 Defrenne v Sabena (Defrenne I) [1976] ECR 455 EU:C:1976:56, paras 57-58; Case C-59/75 Manghera [1976] ECR 91 EU:C:1976:14, paras 19-21.
} 
derogating from them. ${ }^{54}$ The Court's concern seems to be the protection of the settlements agreed at times of Treaty revisions. The Court has been equally hard on 'negative practice' or custom when it is invoked to derogate from a norm of EU primary law that is no longer practised. ${ }^{55}$ It has been more generous in recognising instances of inter-institutional customary law, ${ }^{56}$ however. ${ }^{57}$ Thus, one could mention the confirmation by the Court of the legality of a resolution of the Parliament to hold meetings of its committees and political groups in Brussels ${ }^{58}$ or the legality of the management committee procedure. ${ }^{59}$

At first sight, this reluctance of the Court is surprising because, whether in domestic or international law, courts are the ones vested with the pre-enforcement identification of customary law, and arguably with its validation. There are many reasons one could venture, however. The first one, of course, and the most charitable one, is the lack of relevance of EUCL in practice and hence the few customary norms to actually enforce. The second reason may be that the CJEU in reality resorts to other sources to do what a domestic or international court would usually do with customary law. As a matter of fact, the CJEU uses general principles to fill gaps or to specify indeterminate EU law norms, both functions customary law usually fulfils in domestic and international law. ${ }^{60}$ This is not surprising given how closely related judicial reasoning and general principles are to one another in general. Nor should it come as a surprise given how unconstrained judicial lawmaking generally is in EU law, by comparison to domestic law, but especially to international law.

As I argued before, however, the lack of recognition of EUCL in judicial practice does not take anything away from the latter's independently acquired validity through practice. Nor does it prevent other EU institutions, such as the Council or the Commission, from recognising it, and thereby arguably validating it, if need be.

54 See Case C-174/84 Bulk Oil [1986] ECR 559 EU:C:1986:60, para 65; Case C-68/86 United Kingdom v Council [1988] ECR 855 EU:C:1988:85, para 24; Case C-327/91 France v Commission [1994] ECR I-3641 EU:C:1994:305, para 36; Opinion 1/94 [1994] ECR I-5267 EU:C:1994:384, para 52; Case C-426/93 Germany v Council [1995] ECR I-3723 EU:C:1995:367, para 21; Case C-271/94 Parliament $v$ Council [1996] ECR I-1689 EU:C:1996:133, para 24; Case C-84/94 United Kingdom v Council [1996] ECR I-5755 EU:C:1996:431, para 19; Case C-133/06 Parliament v Council [2008] ECR I-3189 EU:C:2008:257, paras 55-57, 59-60. See also Opinion of AG Maduro in Case C-133/06 Parliament $v$ Council (n 12) paras 26-35. See also Jacqué (n 9) 401; Blanchet and Keller-Noëllet (n 9) 240-41.

55 See Case C-7/71 Commission v France [1971] ECR 1003 EU:C:1971:121, paras 18-22, 23-26.

56 See Case C-25/70 Einfuhr- und Vorratsstelle für Getreide und Futtermittel v Köster and Berodt \& Co [1970] ECR 1161 EU:C:1970:115, paras 6-9; Case C-230/81 Luxembourg v Parliament (n 45) paras 43-46, 48-49; Case C-149/85 Wybot [1986] ECR 2391 EU:C:1986:310, paras 16-17; Case C-137/10 Région de Bruxelles-Capitale [2011] ECR I-3515 EU:C:2011:280, paras 19-22; Opinion of AG Cruz-Villalon in Case C-137/10 Région de Bruxelles-Capitale [2011] ECR I-3515 EU:C:2011:16, paras $48-49$.

57 See Blanchet and Keller-Noëllet (n 9) 242-47.

58 See Case C-230/81 Luxembourg v Parliament (n 45) paras 43-46, 48-49.

59 See Case C-25/70 Köster (n 56) paras 6-9.

60 See eg Kolb (n 3); Tridimas (n 1). 


\section{B. EU Customary Law and the Other Sources of EU Law}

One of the features of the EU legal order, especially by comparison to international law, is that its sources are ranked by reference to one another. One may see this as a sign of the constitutionalisation of EU law, but the hierarchy of sources of EU law may also be justified more generally on grounds of procedural legitimacy.

While EU primary law is usually ranked first and EU secondary law last, a growing trend in recent years has been the distinction, within EU primary law, between a constitutional and superior tier of EU primary law, which includes EU fundamental rights, ${ }^{61}$ and a lower tier. This has consequences in turn for the rank of EUCL in the EU legal order. That rank matters, first, by reference to written sources such as EU primary and secondary law, but also, second, to non-written sources of EU law such as EUGP.

\section{(i) EU Customary Law and the Written Sources of EU Law}

Like EUGP, EUCL is dynamic in its relationship to written EU law. Once it is sufficiently established, it is often codified into written law. Of course, nothing prevents codified EUCL from being interpreted specifically or differently and hence from giving rise to a new subsequent practice and hence to a new custom.

EUCL, especially when it is constitutional, can be codified ('germinated') ${ }^{62}$ into EU primary law, but also, when it is inter-institutional, into inter-institutional agreements. ${ }^{63}$ As a matter of fact, EU primary law has been progressively amended and made more flexible through different instruments of amendment/revision, and this has enhanced these forms of codification of EUCL even further. Furthermore, the recognition of inter-institutional agreements as a source of binding EU law by the Lisbon Treaty (Article 295 TFEU) ${ }^{64}$ or the enhanced co-operation mechanism (Articles $20 \mathrm{TEU}$ and $328 \mathrm{TFEU}$ ) amount to another way in which EU Treaties accommodate within EU primary law inter-state or inter-institutional practices that may become or already amount to EUCL. The CJEU itself has often contributed to the establishment of these constitutional conventions in the making, by turning them into correct interpretations of EU primary law. ${ }^{65}$ As a result, the relationship between EUCL and written sources of EU law is fluid.

Importantly, given the superior rank of EU primary law in the EU legal order, EU primary law is taken as setting constraints on the validity of EUCL. This is one

\footnotetext{
${ }^{61}$ See Joined Cases C-402/05 P and C-415/05 P Kadi (n 39) para 285.

62 See Blanchet and Keller-Noëllet (n 9) 231; Jacqué (n 15) 34-35.

63 See eg Blanchet and Keller-Noëllet (n 9) 218ff; Blumann and Dubouis (n 15) 455-56; Jacqué (n 15) 28ff.

64 See Blanchet and Keller-Noëllet (n 9) 218.

65 See eg Case C-138/79 Roquette frères (n 50) paras 33-36; Case C-139/79 Maizena GmbH v Council of the European Communities [1980] ECR 3393 EU:C:1980:250, paras 27-28.
} 
of the key differences between EUCL and customary international law. Constitutional constraints on customary international law are quite common in domestic law, however. ${ }^{66}$ In EU law, constitutional constraints on EUCL include the following EU primary law rules and principles in particular: rules on the attribution of competences (Articles 4(1) and 5(1) TEU) and the principles of institutional balance (Article 13(2) TEU), of institutional autonomy and of loyal co-operation (Article 4(3) TEU), all of them both inter-state and inter-institutional.

Interestingly, most of these constraints are general principles identified by the CJEU itself, whether or not they have yet been codified into EU primary law. This raises the question of constitutional EUCL and of the applicability of the formal priority of rank of EU primary law to that kind of EUCL. This is a problem currently faced by constitutional EUGP and their relationship to contrary EU primary law. In these cases, as I explained before, formal hierarchies do not seem to help resolving normative conflicts between EUGP and EU primary law norms, thereby leaving their resolution to material normative hierarchies.

The constitutional equivalence of certain norms of EUCL and EU primary law may therefore constitute an exception to the CJEU's ruling that inter-state and inter-institutional EUCL may not contradict or derogate from EU primary law. ${ }^{67}$ The justification for this 'rigid' approach, to quote Advocate General Maduro, to the priority of EU Treaties is the formal procedure of revision of those treaties. ${ }^{68}$ Of course, this argument is understandable when the priority of EU Treaties over EUCL is discussed by contrast to the relationship of equivalence between international treaties and customary international law. It is also envisaged with respect to the relevance of the VCLT in matters of EU Treaties-Article 48 TEU is meant to work as a lex specialis. This is particularly striking with reference to the exclusion of subsequent treaty practice under Article 31(3)(c) VCLT, but also of established practice under Article 5 VCLT or, more generally, of the possibility of treatyderogating customs (indirectly tolerated by Article 39 VCLT) ${ }^{69}$ However, once the issue is approached from an internal EU constitutional perspective, it is unclear that the 'rigid nature of the founding Treaties' can be a sufficient argument in order to rank constitutional EUCL below EU primary law. Conflicts between them should rather be resolved through balancing and by reference to material normative hierarchies when they exist.

\section{(ii) EU Customary Law and the Other Unwritten Sources of EU Law}

Even though the relationship between unwritten sources of EU law is not foreseen by the formal hierarchy of sources of EU law, it is important to consider it

66 See eg Federal Supreme Court of Switzerland, 13 June 2013, Judgement 6B_218/2013, para 3.3.

67 See Case C-68/86 United Kingdom v Council (n 54) para 24; Case C-7/71 Commission v France (n 55) paras 18-22, 23-26; Case C-133/06 Parliament v Council (n 54) paras 55-57, 59-60. See also Opinion of AG Maduro in Case C-133/06 Parliament v Council (n 12) paras 26-35.

68 See Opinion of AG Maduro in Case C-133/06 Parliament v Council (n 12) paras 27-29.

69 See de Witte (n 13). 
carefully, not the least because it may affect our discussion of the relationship between EUCL and EUGP later in this chapter.

Qua unwritten EU law, EUCL should be compared to other unwritten sources of binding and non-binding EU law. The latter include gentlemen's agreements ${ }^{70}$ and other non-binding conventions between EU Member States or institutions. I will focus on the former in this section: they include EUGP and EU judicial law.

First of all, the relationship between EUCL and EUGP. As I explained before, customary law and general principles are usually very difficult to distinguish. This may be explained by reference to the ambivalence about the source of general principles that are sometimes regarded as a type of norms and sometimes as both a type of norms and a source of these norms. Further, the unwritten nature of general principles and the fact that customary law often entails general principles also contribute to their frequent conflation. In international law, the tendency to conflate them has even become strategic since general principles tend to be easier to establish procedurally than customary international law for they do not require a practice. $^{71}$

Curiously, in EU law, this discussion has not yet taken place. There is no trace of it in the CJEU's case law either. This is even more surprising as many EUGP have arisen from inter-state practice, such as EU fundamental rights or the proportionality principle. Moreover, the comparative law method used by the CJEU in ascertaining the existence of some EUGP is reminiscent of the method used by domestic or international courts to establish the inter-state practice constitutive of customary law. Finally, EUGP and EUCL have a certain dependence on judicial reasoning and recognition in common.

Second, EUCL and judicial law-making by the CJEU. When the Court interprets EU law infra or praeter legem, it contributes to its development, thereby contributing to EU law-making writ large. It actually sometimes does so in circumstances where there is an existing inter-state and/or inter-institutional practice. The question that arises in this context is whether EU judicial law should comply with the conditions for the identification or formation of customary law, ie establishing a general, coherent and regular practice and opinio juris, or whether it can expand the scope of EU law without constraints.

This issue arose in the context of the Watson and Belmann case in the 1970s. Advocate General Trabucchi recommended that the Court ascertained the conditions for an inter-institutional and inter-state 'rule of custom and practice' before expanding the personal scope of the principle of free movement of persons to

70 See Blanchet and Keller-Noëllet (n 9) 247-48.

71 See eg ICJ, 15 June 1962, Case concerning the Temple of Preah Vihear (Cambodia $v$ Thailand), Merits, Judgment, ICJ Reports 1962, 23; ICJ, 20 April 2010, Case concerning Pulp Mills on the River Uruguay (Argentina v Uruguay), ICJ Reports 2010, 101. See also P d'Argent, 'Les principes généraux à la Cour internationale de Justice' in S Besson and P Pichonnaz (eds), Les principes en droit européenPrinciples in European Law (Zurich, Schulthess, 2011) 107-20. 
include tourists under EU Treaties. ${ }^{72}$ He was not followed by the Court, however. The CJEU interpreted EU primary law by extending its personal scope without first establishing the existence of an inter-institutional or inter-state custom to that extent and without ascertaining the other conditions for the existence of a custom in that context. ${ }^{73}$ The CJEU's approach to the potential relationship between judicial interpretations of EU law and EUCL confirms the way in which it identifies and develops general principles in its case law, ie without much attention to their sources. EU judicial law or, in the case of EUCL, EU judicial custom seems to be self-sufficient. ${ }^{74}$

\section{(iii) Functions of EU Customary Law}

The functions of EUCL are the same as those of customary law in domestic and international law. As this was famously captured in Article 1(2) Swiss Civil Code, its primary role actually lies in complementing written law. Customary law fills the gaps left by written law, on the one hand, and helps making it more specific when it is indeterminate, on the other.

This has been confirmed for EUCL by Advocate General Maduro. ${ }^{75}$ The CJEU has not been more explicit about the role played by EUCL in the EU legal order. What is clear from the Court's practice, however, is that, when there is EU primary law in place, EUCL may only be used to develop it infra or praeter legem, but never contra legem. EUCL cannot be invoked either to amend ${ }^{76}$ or derogate ${ }^{77}$ from EU primary law. This is a consequence of the primacy of EU primary law mentioned before.

At first sight, the lack of relevance of EUCL in practice does not come as a surprise given its complementary functions. After all, as has been the case in domestic law, the development of the EU legal order and the progressive codification of practices imply a reduced relevance of EUCL over time. The difficulty, however, is that it has always been like that in EU law. ${ }^{78}$ Moreover, this has been the case both for material and constitutional EUCL, whereas domestic constitutional customs tend to remain in place and flourish even in well-established legal orders.

\footnotetext{
72 Opinion of AG Trabucchi in Case C-118/75 Watson and Belmann [1976] ECR 1185 EU:C:1976:79, 1204-05.

73 Case C-118/75 Watson and Belmann [1976] ECR 1185 EU:C:1976:106.

74 See also Blanchet and Keller-Noëllet (n 9) 214-15; Blumann and Dubouis (n 15) 455-56.

75 See Opinion of AG Maduro in Case C-133/06 Parliament v Council (n 12) para 29.

76 See Case C-43/75 Defrenne I (n 53) paras 57-58; Case C-59/75 Manghera (n 53) paras 19-21.

77 See Case C-7/71 Commission v France (n 55) paras 18-22, 23-26; Case C-174/84 Bulk Oil (n 54) para 65; Case C-68/86 United Kingdom v Council (n 54) para 24; Case C-327/91 France $v$ Commission (n 54) para 36; Opinion 1/94 (n 54) para 52; Case C-426/93 Germany v Council (n 54) para 21; Case C-271/94 Parliament $v$ Council (n 54) para 24; Case C-84/94 United Kingdom v Council (n 54) para 19; Case C-133/06 Parliament v Council (n 54) paras 55-57, 59-60. See also Opinion of AG Maduro in Case C-133/06 Parliament v Council (n 12) paras 26-35. See also Jacqué (n 9) 401; Blanchet and Keller-Noëllet (n 9) 240-41.

78 See also Pescatore (n 8) 174.
} 
The grounds for the sidelining of EUCL are to be found elsewhere, as a result. There are at least four reasons one could put forward for the limited role of EUCL in the EU legal order: the supranationality of EU law, its democratic legitimacy, its complex vertical and horizontal division of powers, and its jurisprudential nature.

First of all, the supranationality of EU law. One of the specificities of the EU qua international organisation is its supranational nature. This may be verified in numerous features of its legal order, but especially in the EU law-making process. The sources of EU law are such that EU Member States are no longer the sole lawmakers. This even applies to the EU Treaties whose adoption and revision procedures include EU institutions. Some of them represent the interests of Member States albeit on majoritarian grounds (Council), while others represent EU citizens (Parliament) or even the interest of the EU itself (Commission) (Article 10 TEU). No wonder, then, that a source such as EUCL whose subjects could be either states or institutions only does not fare very well in this supranational setting. Of course, nothing precludes certain normative practices and hence EUCL from being both inter-state and inter-institutional, thereby abiding by the supranational specificity of EU law. This was actually Advocate General Trabucchi's argument in the context of the free movement practice in Watson and Belmann. ${ }^{79}$ Thus, whereas EUCL may at first seem to be at odds with supranational EU law-making, it is in fact compatible with it provided it is both inter-state and inter-institutional.

Secondly, the democratic legitimacy of EU law. Another characteristic of the EU's supranational legal order is that its legitimacy is democratic and hence ultimately grounded in the political equality of EU citizens (Article 9 TEU). More specifically, it is through the involvement of the European Parliament in most EU law-making procedures that EU law's democratic justification is acquired. Even if inter-state EUCL may be said to be indirectly democratic to the extent that it is through the general practice of democratic Member States that it is adopted, the implication of the EU Parliament qua requirement of supranational democracy is not necessarily given. The same may be noted of some instances of interinstitutional EUCL in which the equal participation of the European Parliament is not necessarily granted. It is without surprise therefore that the lack of democratic legitimacy also underpins Advocate General Maduro's rejection of derogatory EUCL: he refers to 'EU citizens' and to the 'reinforced legitimacy' of the EU Treaties. ${ }^{80}$ Of course, there is a paradox in considering EUCL as lacking indirect democratic credentials when EUGP are increasingly used in the CJEU's case law, including in order to derogate from EU Treaties, and without any reference to either EU citizens' or the EU Parliament's approval.

Thirdly, the complex horizontal and vertical division of powers in EU law. Another feature of the EU legal order is its complex division of powers. It is a combination of horizontal (between EU institutions) and vertical (between EU

79 Opinion of AG Trabucchi in Case C-118/75 Watson and Belmann (n 72) 1204-05.

80 See Opinion of AG Maduro in Case C-133/06 Parliament v Council (n 12) para 29. 
Member States and the EU) division, the former replicating some of the latter to a certain extent. The way in which EUCL is made may at first be considered as a threat to this sensitive balance of powers. ${ }^{81}$ After all, even when it arises from a combination of inter-state and inter-institutional practice, it is difficult to see how it could abide perfectly by the constitutional constraints and procedures set by the EU Treaties to respect that balance. In those conditions, the fear is that EUCL could contribute to the 'competence creep' already at work in the EU. Interestingly, however, EUGP themselves have also been criticised for contributing to that 'competence creep', as I explained before. In this respect, one may consider the combined inter-state and inter-institutional dimension of EUCL as vouching for a greater respect of the sensitive vertical and horizontal balance of powers within the EU. After all, EUCL derives from inter-state and inter-institutional practice and opinio juris, and hence from what both the Member States and institutions see as being the right division of powers in practice.

Finally, the jurisprudential nature of EU law. The CJEU has played a crucial role in the development of the EU legal order qua autonomous legal order. Nowhere is that role more tangible than in the context of the sources of EU law: they have been gradually moulded by the Court, whose role has been to ascertain norms arising from these sources and sometimes even to validate them. The lack of case law, and of careful reasoning, about EUCL in the Court's practice may be explained by the very role the CJEU plays within the EU legal order itself. This came out clearly from its reasoning in Watson and Belmann, and from the hiatus between the proposed reasoning in the Advocate General's opinion and the Court's. The Court does not see the need to justify its reasoning by grounding it in (other) sources of EU law. In turn, this explains why it is not interested in identifying new constraints on its reasoning based on inter-state or inter-institutional practice. As a matter of fact, this accounts for the comparative advantage of EUGP over EUCL for the CJEU: EUGP are easier to establish than EUCL, do not constrain judicial reasoning as much as EUCL and fulfil some of the gap-filling functions of EUCL. In other words, the CJEU prefers to claim the autonomy of EU law and to avoid reliance on EUCL exactly because it gives itself more flexibility. If it had to identify customary principles at Member State level, it could never have decided cases such as Omega or Mangold in the way it did.

Interestingly, some of these grounds for the limited role of EUCL in practice are currently under strain. This is because the EU is changing internally, but also externally in its relationship to other states and international organisations.

First of all, the return of inter-state law in the EU. There has been a clear intergovernmental trend at play within the EU since 2011. This has in particular led to the (re)introduction of international law methods and sources in the relations between EU Member States, including on issues which would have been dealt with through the méthode communautaire and through EU law at earlier times.

81 See Blanchet and Keller-Noëllet (n 9) 213. 
It suffices to mention the various inter-state treaties concluded in the wake of the financial crisis since 2008, but also the ways in which these instruments have led to the twisting or softening of the EU constitutional framework. ${ }^{82}$ Of course, the EU Treaty crisis is not a new phenomenon: it has been with us since 2004 and the failure of the Constitutional Treaty. What is new, however, is that the increased flexibilisation introduced or revised in the EU Treaties at Lisbon (eg simplified revision procedures under Article 48 TEU, flexibility clause under Article 352 TFEU or enhanced co-operation under Article $20 \mathrm{TEU}$ ) have not managed to bring EU Member States back to EU primary law. On the contrary, Member States have retreated into the inter-governmental periphery, both in terms of institutions and sources of law-making. Under these circumstances, one should make a virtue of a necessity, and bring inter-state conventions and customs back into the scope of EU law by broadening the sources of EU law. ${ }^{83}$ This would ironically ensure that the constitutional and democratic constraints of EU law are respected. Maintaining the integrity of the EU legal order may now come at this price.

Secondly, the questioning of judicial law in the EU. The role of the Court in EU law-making is being challenged, especially when contrasted with that of EU Member States. Of course, the opposition between legislation and judicial law is common in any democracy. What is specific in the EU, however, is that it is also a polity of democratic states. ${ }^{84}$ This implies that the democratic legitimacy of judicial law also needs to be accounted for from an inter-state perspective. In this context, one may hope the CJEU could refer more regularly and more rigorously to EUCL to support its reasoning and interpretations in the future. This is even more important after Opinion 2/13 and the direction in which the CJEU is leading the Member States in terms of international law. ${ }^{85}$

\section{General Principles qua EU Customary Law}

Based on the previous sections, I would now like to argue that some general principles of EU law, ie those that derive from the Member States' legal orders, are best approached as customary law principles (IV.A). I will illustrate this point in a specific context, that of EU fundamental rights (IV.B).

82 See M Dawson and F de Witte, 'Constitutional Balance in the EU after the Euro-Crisis' (2013) 76 Modern Law Review 817-44. See also Case C-370/12 Pringle [published in the electronic Reports of Cases] EU:C:2012:756; Case C-62/14 Gauweiler and Others [nyr] EU:C:2015:400.

${ }^{83}$ See Blanchet and Keller-Noëllet (n 9) 250-51.

84 See S Besson, 'European Human Rights, Supranational Judicial Review and DemocracyThinking Outside the Judicial Box' in P Popelier, C Van de Heyning and P Van Nuffel (eds), Human Rights Protection in the European Legal Order: The Interaction Between the European and the National Courts (Cambridge, Intersentia, 2011) 97-145.

85 See PJ Kuijper, 'Reaction to Leonard Besselink's ACELG Blog', https://acelg.blogactiv. eu/2015/01/06/reaction-to-leonard-besselinks\%E2\%80\%99s-acelg-blog/, accessed 1 September 2015. 


\section{A. Sources of General Principles Common to the Laws of the Member States}

Many EUGP arise from inter-state practice and come very close to customary general principles. This is clearly the case of the EUGP that are 'common to the laws of EU Member States'. While these principles are one out of four types of EUGP, they are also the most specific ones in EU law and the kind of general principles that have been most prevalent in the EU legal order.

As a matter of fact, EUGP and EUCL are even more intimately related than general principles and custom in other legal orders. Indeed, they share similar identification and formation criteria. First of all, the comparative law method used by the CJEU in ascertaining the existence of some EUGP ${ }^{86}$ is reminiscent of the method used by domestic or international courts to establish the interstate practice constitutive of customary law. Secondly, the inter-state practice the CJEU is after is general only, and need not be unanimous for a general principle to be considered as sufficiently common to become an EU general principle. Thirdly, the reference to domestic case law in that context comes close to the establishment of EU Member States' opinio juris: the practice of domestic courts is indeed evidence of the grounds for compliance behind the practice.

All this confirms that EUCL could in fact be regarded as the source of some EUGP. If this is the case, it is important the CJEU acknowledges and complies with customary law reasoning in all cases pertaining to the general principles common to EU Member States.

This would be particularly justified now that the increasing relevance of EUGP in the EU legal order and their development by the CJEU are facing challenges. Some of these challenges could indeed be met were the customary source of some EUGP clearly recognised and the Court's reasoning adapted accordingly. This is the case primarily of the need to enhance the constraints on the CJEU's law-making powers and judicial reasoning. EUCL has indirect democratic credentials that derive from (non-judicial) inter-state practice that EUGP do not have in this respect. A second challenge lies in the 'competence creep' through EUGP that some have identified in practice. ${ }^{87}$ The customary law-ascertainment process in the Court's reasoning could contribute to make those principles more attuned to an inter-state and inter-institutional practice in a given area and hence to preserving the allocation of powers within the EU.

86 See Case C-11/70 Handelsgesellschaft (n 29).

87 See eg Prechal (n 36). 


\section{B. EU Fundamental Rights qua EU Customary Law}

Among the EUGP that stem from EU Member States' common principles, the most historical and fundamental ones in the EU legal order are EU fundamental rights. They developed as general principles through the CJEU's case law. ${ }^{88}$

As a matter of fact, EUGP are still recognised as a source of these rights now that EU fundamental rights have been codified into the EU Fundamental Rights Charter (Article 6(3) TEU; Article 52(4) EUFRC; Preamble to the EUFRC) and in other parts of EU primary and secondary law. True, from 2010 onwards, the Charter has been treated as a starting point in the CJEU's reasoning on EU fundamental rights. ${ }^{89}$ However, this has not always been followed strictly. Importantly, moreover, this does not imply a priority in reasoning with either a Charter right or a general principle, nor a formal hierarchy in case of conflict between them. As I explained before, indeed, the normative relations between EUGP, on the one hand, and between EUGP and other sources of EU law, on the other, do not fit the formal hierarchy of sources very well in practice. Thus, no formal priority or hierarchy should be assumed between the EU fundamental rights of Article 6(1) and (3) TEU depending on their respective sources (see also Article 52(4) EUFRC a fortiori). ${ }^{90}$

Based on my argument in the previous section, EU fundamental rights could actually be approached as customary in source. Not only does this interpretation fit the sources of EU fundamental rights, but it also best justifies their specificities.

In terms of sources, on the one hand, EU fundamental rights are said to arise bottom-up from EU Member States' respective internal practices of fundamental rights. Once there is sufficient commonality in that practice, even if it is not unanimous as confirmed by the CJEU in the Omega case, ${ }^{91}$ these rights may become EU fundamental rights. Moreover, EU fundamental rights work as protection maxima and not as minimal thresholds of protection. ${ }^{92}$ Both features are best explained by reference to their customary source.

${ }^{88}$ See eg Case C-29/69 Stauder [1969] ECR 419 EU:C:1969:57, para 7; Case C-4/73 Nold [1974] ECR 491 EU:C:1974:51, para 13; Case C-11/70 Handelsgesellschaft (n 29) paras 3-4. See, more recently, Case C-521/09 P Elf Aquitaine v Commission [2011] ECR I-8947 EU:C:2011:620, para 112; Case C-571/10 Kamberaj [published in the electronic Reports of Cases] EU:C:2012:233, paras 60-61.

89 See eg Joined Cases C-92/09 and 93/09 Volker und Markus Schecke and Eifert Schecke [2010] ECR I-11063 EU:C:2010:662; Case C-236/09 Association Belge des Consommateurs Test-Achats and Others [2011] ECR I-773 EU:C:2011:100.

90 See H Hoffmann and B Mihaescu, 'Relation between Charter's Fundamental Rights and Unwritten General Principles' (2013) 9 European Constitutional Law Review 73-101, 77-82. See also Case C-604/12 HN [nyr] EU:C:2014:302.

91 See Case C-36/02 Omega (n 30) paras 34-35.

92 See LFM Besselink, 'Entrapped by the Maximum Standard: On Fundamental Rights, Pluralism and Subsidiarity in the European Union' (1998) 35 Common Market Law Review 629-80 and JHH Weiler, 'Fundamental Rights and Fundamental Boundaries: On the Conflict of Standards and Values in the Protection of Human Rights in the European Legal Space' in JHH Weiler, The Constitution of Europe (Cambridge, Cambridge University Press, 1999) 102-29. See also Case C-550/07 P Akzo Nobel Chemicals and Akcros Chemicals v Commission [2010] ECR I-8301 EU:C:2010:512. 
On the other hand, the customary approach to EU fundamental rights best accounts for their specificities in practice.

First of all, the function of EU fundamental rights may be compared neither to domestic (federal) fundamental rights nor to international fundamental rights. ${ }^{93}$ This can be checked easily by reference to their personal (Article 51(1) EUFRC) ${ }^{94}$ and material scope (Article 51(1) EUFRC), but also to their maximal rather than minimal nature (Article 53 EUFRC). ${ }^{95}$ These two features are best justified if the sources of EU fundamental rights are considered to be transnational and to grow out of the intra- and inter-state practice of EU Member States, rather than imposed top-down and in a centralised fashion on them. Second, there is no general human rights competence of the EU. EU fundamental rights have indeed grown out of domestic fundamental rights in joint spheres of competence. ${ }^{96}$ The customary account of the sources of EU fundamental rights therefore succeeds in squaring the human rights duties of EU Member States nicely with the principle of conferral of powers.

Third, EU fundamental rights are only rarely applied and interpreted in conjunction with international human rights (except for the ECHR on grounds of Article 53(3) EUFRC). This is best justified by reference to the customary and transnational nature of EU fundamental rights: it is because EU fundamental rights have grown from the inside and from each Member State's practice as an integrated ${ }^{97}$ fundamental rights regime that they are not concerned with minimal external guarantees that apply directly to those Member States' own fundamental rights regimes. Finally, EU fundamental rights work as unwritten constitutional constraints on EU primary law. This is best justified again once their sources are considered as customary and concurrent to EU primary law, rather than internal to the latter (see also Article 52(4) EUFRC a fortiori with respect to the Charter itself and Article 6(1) TEU). This is a common argument made about domestic constitutional customary law and its role as supra-constitutional constraint.

${ }^{93}$ Of course, with the development of EU democracy and citizenship, this intermediary transnational position held by EU fundamental rights has become increasingly uncomfortable: see eg Case C-617/10 Akerberg Fransson [published in the electronic Reports of Cases] EU:C:2013:105, para 29 and Case C-399/11 Melloni [published in the electronic Reports of Cases] EU:C:2013:107, para 60. See S Besson, 'The Bearers of Human Rights Duties and Responsibilities for Human Rights-A Quiet (R)Evolution' (2015) 32 Social Philosophy \& Policy 244-268, 265-66.

94 See Case C-617/10 Fransson (n 93) para 29.

95 See Case C-399/11 Melloni (n 93) para 60.

96 See S Besson, 'The Human Rights Competence in the EU-The State of the Question after Lisbon' in G Kofler, M Poiares Maduro and P Pistone (eds), Taxation and Human Rights in Europe and in the World, 5th GREIT Conference (Amsterdam, IBFD, 2011) 37-63.

97 See P Eeckhout, 'Human Rights and the Autonomy of EU Law: Pluralism or Integration?' (2013) 66 Current Legal Problems 169-202. See also S Besson, 'Human Rights and Constitutional Law: Mutual Validation and Legitimation' in S Rowan Cruft, M Liao and M Renzo (eds), Philosophical Foundations of Human Rights (Oxford, Oxford University Press, 2015) 279-99; S Besson, 'European Human Rights Pluralism-Notion and Justification' in M Poiares Maduro, K Tuori and S Sankari (eds), Transnational Law-Rethinking European Law and Legal Thinking (Cambridge, Cambridge University Press, 2014) 170-205. 
One should therefore hope for more consideration of the customary source of EU fundamental rights in future reasoning by the CJEU. Some authors, such as Grainne de Búrca, ${ }^{98}$ have actually already recommended, albeit on different grounds, that the Court resorts to a more rigorous comparative law method in its human rights reasoning. ${ }^{99}$ This would actually merely imply a return to the comparative fundamental rights reasoning used by the Court in its original decisions on fundamental rights. ${ }^{100}$

\section{Conclusions}

The doctrine of sources constitutes an interesting angle to grasp the comparative nature and role of EUGP in the EU legal order. Unlike previous research on the topic, this chapter's comparative focus has not been on their relationship to EU primary law, but to another source of unwritten EU law: EUCL.

Contrary to what is the case in domestic and international law, customary law has been largely neglected in the EU legal order, and so has its relation to EUGP. This is particularly striking as the latter relationship has long obsessed domestic and international lawyers. There have been different reasons for these debates in domestic and international law: both general principles and customary law are unwritten sources of law, and they actually share some dimensions in their identification and formation processes; there is an ambivalence between general principles qua source and qua type of norms, and customary law is actually the source of many principles qua norms; finally, that ambivalence has been used strategically, especially in international law, to escape the conditions of identification and formation of one or both sources.

This chapter started by fleshing out the comparative imbalance in EU law between the qualitative and quantitative importance of EUGP and the relative irrelevance of EUCL. Some reasons for the reluctance towards EUCL in EU law have been identified and then debunked in the chapter: the supranationality of EU law, its democratic legitimacy, its idiosyncratic vertical and horizontal division of powers, and its jurisprudential nature. The chapter also explained how some of these grounds are currently under strain and are turning into arguments

\footnotetext{
98 See G de Búrca, 'After the Charter of EU Fundamental Rights: The Court of Justice as a Human Rights Adjudicator?' (2013) 20 Maastricht Journal of European and Comparative Law 168-184, 171-4.

99 On comparative or transnational human rights law in general, see eg Besson (n 97); S Besson, 'Human Rights as Transnational Constitutional Law' in A Lang and A Wiener (eds), Global Constitutionalism Handbook (London, Edward Elgar, 2017, forthcoming); C McCrudden, 'A Common Law of Human Rights: Transnational Judicial Conversations on Human Rights' (2000) 20 Oxford Journal of Legal Studies 499-532, 530.

100 See eg Case C-29/69 Stauder (n 88); Case C-4/73 Nold (n 88); Case C-11/70 Handelsgesellschaft (n 29).
} 
for EUCL. The EU is changing internally, but also externally in its relationship to other states and international organisations. In these circumstances, EUCL may have a new role to play, especially in light of two important challenges: the role of international law in the EU and the growing critique of the role of the CJEU.

After exploring EUGP's and EUCL's respective types, sources (respectively, source-based relations) and functions in EU law by comparison to domestic and international law, this chapter uncovered and explained some of their ties both in terms of functions and of sources. On that basis, it argued that the most important EUGP for the development of the EU legal order, ie the general principles common to the laws of EU Member States, are best understood as customary law principles. This approach accounts in particular for their convergent practice of identification that is comparative, general and judicial. The argument was then exemplified in the field of EU fundamental rights. The proposed customary reading of EU fundamental rights not only accounts for the practice of identification of these rights and their role in EU law, but justifies some of their specific traits, and in particular: their transnational nature by contrast to both domestic or international human rights law; their remote relation to international human rights law; their concurrent relationship to EU primary law; and the lack of a general fundamental rights competence of the EU.

The upshot of the proposed argument is the enhanced legitimacy of EUGP qua EUCL. The customary reading helps to address some of the current challenges facing EUGP. It makes those principles arguably less dependent on judicial law and the CJEU, more comparative and less threatening to the vertical and horizontal allocation of powers within the EU. In the context of EU fundamental rights, this argument is also a signal to the CJEU whose future case law on human rights could gain in democratic legitimacy were it to be more comparative and attuned to the domestic practices of EU Member States. 
